\title{
Two new synonyms of Pertusaria coccodes (Pertusariales, Ascomycota)
}

\author{
Magdalena Oset \\ Department of Plant Taxonomy and Nature Conservation, Faculty of Biology, University of Gdańsk, Wita Stwosza 59, \\ 80-308 Gdańsk, Poland. E-mail: magdalena.oset@ug.edu.pl
}

\begin{abstract}
Pertusaria atropallida and $P$. uralensis are found to represent synonyms of the lichenized fungus $P$. coccodes. Lectotypes are selected for $P$. atropallida and $P$. uralensis.
\end{abstract}

Keywords: lichen, Pertusariaceae, typification, taxonomy

\section{INTRODUCTION}

The lichen genus Pertusaria DC. s.1. (Pertusariales, Ascomycota) is characterized by crustose, continuous to cracked thalli (in many taxa with isidia or soredia), usually large apothecia with open or perithecia-like discs, 1-8-spored asci with thick walls, and large and simple ascospores with thick, simple layered or laminate walls which are uniform, ornamented or striate. Secondary lichen metabolites are very diverse in Pertusaria and include depsides, depsidones fatty acids and xanthones (Dibben, 1980; Archer, 1993, 1997; Chambers et al., 2009). The genus is cosmopolitan, and its members are found from the Arctic and Antarctic to the tropics in both Hemispheres. About 800 species of Pertusaria s.1. are known worldwide, many of them with several varieties, which actually usually may represent habitat modification only and are unworthy of highlighting (Tobolewski, 1972; Dibben, 1980; Archer, 1993; Lumbsch \& Nash, 2001; Archer \& Elix, 2018 and literature cited therein). Nevertheless, there are still significant gaps in the distribution of many taxa in different regions of the world and many uncertainties related to taxonomy within the genus.

During a revision of the type materials of Pertusaria DC. in the Herbarium of the Turku University (TUR-V) collections named Pertusaria atropallida Vain. and $P$. uralensis Vain., which appeared to be synonyms of $P$. coccodes (Ach.) Nyl. The species Pertusaria atropallida was described from Näränkävaara Mt. (Kuusamo, Finland) as growing on the bark of fir (Wainio, 1881). According to the protologue, the species has \pm rimose-cracked, yellowish-white or yellowish-pink thallus with smooth upper surface without zoned margin, isidia densely covering parts of the thallus, immersed apothecia with black discs, and simple ascospores measuring 30-80 × 24-40 $\mu \mathrm{m}$. Pertusaria uralensis was reported only from Russia „prope Stationem Uralskaja in Montibus Uralensibus" (Vainio, 1928). The species is characterized by lacking isidia or soredia, and with 2-4 ostiolate apothecia, but without ascospores. Thallus reacts $\mathrm{K}^{+}$ yellow then turning red.

\section{MATERIAL AND METHODS}

The study is based on specimens deposited in TUR. Additional specimens from B, H, KRA, KRAM, SLTC, TRN, UGDA and UPS were studied for comparison (almost 140 specimens were examined). All samples were examined for anatomical, morphological and chemical characters. The morphology of the specimens was studied using a stereomicroscope. The following characters were examined: thickness, structure and colour of thallus, colour, shape and size of isidia and soredia. Anatomy was examined in handmade section or squash preparations mounted in water or $\mathrm{KOH}$ (in case of deformed ascospores in old specimens). Secondary metabolites were identified by thinlayer chromatography (TLC; solvents A and C) according to the methods proposed by Culberson \& Kristinsson (1970), White \& James (1985) and by Orange et al. (2001); metabolites reported refer to those detected in type material and other studied specimens.

Locality information is provided here in the same form as written on the original labels. 


\section{RESULTS \& DISCUSSION}

Two herbarium specimens (TUR-V 6743, 6744) were found to represent original material of $P$. atropallida. TUR-V 6743 is annotated "Fennia, Kuusamo, Näränkävaara" and has original note "e specim. orig.", while TUR-V 6744 is annotated "Kuusamo, Näränkävaara" and is designated as " $n$. sp." Information on labels and morphological characters correspond to the description in the protologue, but E. Vainio did not determine any specimen as a holotype, therefore lectotype should be selected (Art. 9.11; Turland et al., 2018). Because the specimen TUR-V 6744 is accompanied by original description with handwritten notes of E. Vainio, it should be designated as lectotype, while TUR-V 6743 as its duplicate (isolectotype). However, the situation is more complicated as the name $P$. atropallida is based on two organisms, because the original material includes sterile lichenized thalli and black perithecioid ascomata of a lichenicolous fungus, and both elements were apparently used for the species description.

The lichenized thallus present in the material is isidiate and contains norstictic acid as found by thin layer chromatography (TLC) and fits well the current concept of $P$. coccodes (Chambers et al., 2009). Meanwhile, the ascomatal structures described by Wainio (1881) clearly refer to lichenicolous fungus as no other immersed ascomata were detected. I sectioned four perithecioid ascomata, but no ascospores were found. Since no lichenicolous fungus growing on Pertusaria has similar size of ascospores as reported by Wainio (1881), the identity of the fungus species remains unknown.

As the material of $P$. atropallida belongs to more than one taxon, one has to be selected as the lectotype (Art. 9.11 and Art. 9.14; Turland et al., 2018). In order to keep the name in the genus Pertusaria, it is proposed to typify $P$. atropalli$d a$ with the thallus and this name should be considered a synonym of $P$. coccodes.

Additional specimens of $P$. atropallida collected by $\mathrm{E}$. Vainio was deposited in the herbarium of University of Helsinki (H 9505289) and was studied by M. J. Dibben and V. Alstrup. This specimen should be treated as isolectotype.

The original material of $P$. atropallida was also reported from the Herbarium Hamburgense
(HBG) by Hanko (1983) and is cited as "Finland. Oulu: Kuusamo (Mt. Näränkävaara), 1877, Wainio (HBG-888)" with handwritten note "Original" by C. F. E. Erichsen (Hanko, 1983). Probably the specimen was sent by E. Vainio to C. F. E. Erichsen and can be treated as isolectotype, not as holotype as stated by Hanko (1983).

Pertusaria uralensis was reported as growing on bark of Abies sibirica „prope Stationem Uralskaja in Montibus Uralensibus” (Vainio, 1928). Since then, it has not been reported from any additional locality. Vainio (1928) characterized the species as having thallus reacting $\mathrm{K}+$ yellow then turning red (red crystals developing) and lacking isidia or soredia, and with 2-4 ostiolate apothecia, but without ascospores. The examination of original material (TUR-V 6802) revealed few globose, locally developing isidia and the presence of norstictic acid. Morphologically and chemically $P$. uralensis is indistinguishable from $P$. coccodes (Chambers et al., 2009), and therefore it is here reported as a synonym of the latter species.

Vainio (1928) did not determine any specimen as a holotype in the protologue, and only locality was reported. Therefore lectotype has to be selected, because it is not possible to determine that at the time of describing the species E. Vainio had only one element upon which the validating description was based (Art. 9.3; Turland et al., 2018; see also McNeill, 2014).

The new synonymy of $P$. coccodes are as follows:

PerTusaria Coccodes (Ach.) Nyl.

Mém. Soc. Imp. Sci. Nat. Cherbourg 5: 116 (1857). basionym: Lichen coccodes Ach., Lich. suec. prodr. (Linköping): 10 (1799) [1798].

= Pertusaria atropallida Vain., Meddeland. Soc. Fauna Fl. Fenn. 6: 180 (1881), syn. nov.

Lectotype (designated here): Finlandia, Kuusamo, Kuusamon pit., Näränkävaara, Kuusen kuorella kuusimetsässä, 1877, E. Wainio (TUR-V 6744!, thallus of Pertusaria coccodes; isolectotypes; TUR-V 6743!, H 9505289!, HBG!).

= Pertusaria uralensis Vain., Ann. Acad. Sci. Fenn., Ser. A, 27: 80 (1928), syn. nov.

Lectotype (designated here): Rossia, Jugum Uralense, Uralskaja. Pichta, 1880, E. Wainio (TUR-V 6802!). 


\section{ACKNOWLEDGMENTS}

I express my gratitude to Martin Kukwa (Poland) for his valuable comments and suggestions. I also would like to thank Tevuo Ahti, Leena Myllys (Finland) and Zdeněk Palice (Czech Republic) for help with the literature, Leena Myllys (Finland) for sending material of Pertusaria atropalli$d a$ and J. McNeill (Toronto) for comments on the typification of $P$. uralensis. I thank anonymous reviewers for all constructive corrections and valuable comments.

\section{REFERENCES}

Archer, A. W. 1993. A chemical and morphological arrangement of the lichen genus Pertusaria. Bibliotheca Lichenologica 53: 1-17.

Archer, A. W. 1997. The lichen genus Pertusaria in Australia. Bibliotheca Lichenologica 69: 1-249.

Archer, A. W. \& Elix, J. A. 2018. A preliminary world-wide key to the lichen genus Pertusaria (including Lepra species). https://www.rbgsyd. nsw.gov.au/getmedia/02569f19-bddb-48659155-6156d95939f1/Revised-Pertusaria-keyfinal-August-2018.pdf.aspx [Accessed 08.01.2021].

Chambers, S. P., Gilbert, O. L., James, P. W., Aptroot, A. \& Purvis, O. W. 2009. Pertusaria DC (1805). In: Smith, C. W., Aptroot, A., Coppins, B. J., Fletcher, A., Gilbert, O. L., James, P. W. \& Wolseley, P. A. (eds). The lichens of Great Britain and Ireland. London. British Lichen Society, London, pp. 673-687.

Culberson, C. F. \& Kristinsson, H. 1970. A standardized method for the identification of lichen products. Journal of Chromatography A 46: 85-93. https://doi.org/10.1016/S0021-9673(00)839679

Dibben, M. J. 1980. The chemosystematics of the lichen genus Pertusaria in North America North of Mexico. Publications in Biology and Geology, Milwaukee Public Museum 5: 1-162.
Hanko, B. 1983. Die Chemotypen der Flechtengattung Pertusaria in Europa. Bibliotheca Lichenologica 19: 1-297. https://doi.org/10.1111/j.1756-1051. 1986.tb00889.x

Lumbsch, H. T. \& Nash, T. H. 2001. Pertusaria. In: Nash, T. H., Ryan, B. D., Gries, C. \& Bungartz, F. (eds.). Lichen Flora of the Greater Sonoran Desert Region 1: 341-357.

McNeill, J. 2014. Holotype specimens and type citations: General issues. Taxon 63: 1112-1113. http://dx.doi.org/10.12705/635.7

Orange, A., James, P. W. \& White, F. J. 2001. Microchemical methods for the identification of lichens. British Lichen Society, London, $101 \mathrm{pp}$.

Tobolewski, Z. 1972. Porosty klucz do oznaczania gatunków krajowych. PWN, Warszawa. 251 pp. (In Polish).

Turland, N. J., Wiersema, J. H., Barrie, F. R., Greuter, W., Hawksworth, D. L., Herendeen, P. S., Knapp, S., Kusber, W.-H., Li, D.-Z., Marhold, K., May, T. W., McNeill, J., Monro, A. M., Prado, J., Price, M. J. \& Smith, G. F. (eds.) 2018. International Code of Nomenclature for algae, fungi, and plants (Shenzhen Code) adopted by the Nineteenth International Botanical Congress Shenzhen, China, July 2017. Regnum Vegetabile 159: 1-254. https://doi. org/10.12705/Code.2018

Vainio, E. A. 1928. Enumeratio lichenum in viciniis fluminis Konda (circ. $60^{\circ}$ lat. bor.) in Sibiria occidentali crescentium. Annales Academiae Scientiarum Fennicae. Ser. A 27(6): 65-122.

Wainio, E. A. 1881. Adjumenta ad Lichenographiam Lapponie fennice atque Fenniae borealis. Meddelanden af Societas pro Fauna et Flora Fennica 6: 77-182.

White, F. J. \& James, P. W. 1985. A new guide to microchemical techniques for the identification of lichen substances. The British Lichen Society 57 (Suppl.): 1-41. 